\title{
Ethics And Corporal Punishment Within The Schools Across The Globe
}

Usha Rajdev, Marymount University, USA

\begin{abstract}
This paper contains cultural anthropological research on various discipline measures used within the classrooms in India, United Kingdom, China, Africa, and the United States. My recent visit to schools in India on study abroad programs prompted my desire to research across the globe different methods of classroom management discipline conducted within the schools. Findings suggest that corporal punishment is being favored among most countries. Hitting or yelling at a child, a common practice in some schools is not ethically acceptable by me, as an educator, nor by my students who witnessed several incidences whilst in India. We were caught in the ethics verses culturally acceptable norm 'dilemma'. The purpose of this paper is not to devise specific discipline measures at this juncture, but rather to investigate the acceptable practices within the classrooms in the above stated countries. Implications for this only further my ethical obligations and challenges that lie ahead.
\end{abstract}

Keywords: School Corporal Punishment; Teacher Ethics; Classroom Management; Classroom Discipline

\section{INTRODUCTION}

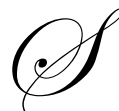

ince the study abroad program conducted in India in January 2010 and 2011, I have become more aware of the differences in expectations of disciplining children in the classrooms across the globe. This awareness not only became apparent, but rather disturbing for me when I observed and participated in the teaching and learning service project, in Porbandar, India (Gandhi's birth place). After some considerations of my personal ethical views on disciplining children and being fully aware of the future study abroad programs in Porbandar, I decided to better inform my students and 'be the change I (they) want to see' (extrapolated from Gandhi's quotes). By this I mean placing an emphasis in modeling positive classroom discipline methods for my students during my methodology classes. The research was on the students' discipline and regulations implemented in the countries that interested me. I either taught or studied in all the selected countries except China.

India

In 2000, the Delhi High Court ruled that the provisions for corporal punishment in the Delhi School Education Act (1973) were inhumane and detrimental to the dignity of children. The National Commission for the Protection of Child Rights (NCPR) has recommended the abolition of corporal punishment in all schools. Also according to Roa in, "Positive Discipline in the Classroom: Spare the Rod and Save the Child" the Supreme Court stated that children should not be subjected to corporal punishment in schools and that they receive education in an environment of freedom and dignity, and free from fear.

Vaidya Gullipalli (2009) in her INDIA: A chance to rethink school discipline, "Despite vigorous and unambiguous efforts to eliminate corporal punishment, the practice persists in schools around the world. Violence is a part of the lives of those children who experience and witness it and their physical safety is compromised in one of the spaces in which they should be most protected." She went on to report that in 2007 it was revealed that twothirds of children around the country reported undergoing some form of corporal punishment, while that very year the national commission for the protection of child rights had told all state governments that the practice had to be "nipped in the bud". According to this article, corporal punishment will be difficult to eliminate unless teachers are effectively trained in alternative forms of discipline and behavior management. The high expectations imposed by 
parents on their children's performance in schools places a great deal of pressure on the teachers. Traditional teaching is expected of teachers while a high performance rate is expected of students. I witnessed during my visits and previous years of teaching that 'teachers taught and students wrote' to the degree of perfecting their work. They feared repercussions if their writing was off the lines, their calculations were incorrect, or if they stepped out of line whilst walking. Teachers were seen, by both my students and me, smacking the students.

UN Committee on the Rights of the Child in the General Comment No. 8 (2006) defines 'corporal' or 'physical' punishment as, "any punishment in which physical force is used and intended to cause some degree of pain or discomfort, however light. Most incidents involve hitting ("smacking", "slapping", "spanking") children, with the hand ... In the view of the Committee, corporal punishment is invariably degrading. These include, for example, punishment which belittles, humiliates, denigrates, scapegoats, threatens, scares or ridicules the child."

In the UNICEF article, 'All You Want to Know About Corporal Punishment' it was stated that two out of three school children in India are physically abused as stated in the national report on child abuse by the Ministry of Women and Child Development in 2007. Boys are marginally more likely to face physical abuse (73 percent) than girls (65 percent). Corporal punishment in both government as well as private schools is deeply ingrained as a tool to discipline children and as a normal action. I believe that most children tend to remain silent and become fearful of confiding about the pain to anyone lest they face further consequences. What about a moral right that children possess?

Michael Boylan, 2011, states that children possess (in actuality) many characteristics that deserve respect (despite their status as protected individuals). Thus, children possess dual rights claim: (a) from their status as protected potential agents, and (b) from their actual personal ground of dignity that is born from their individual narratives (autonomy).

The UN Study on Violence against children (2006) recommended in its final report prohibiting all corporal punishment of children. This large body of international research detailed the negative outcomes of corporal punishment. Campaigning for law reform to prohibit corporal punishment: Understanding the need for prohibition Summary Briefing 1 (June 2009), the study states that teacher training and sensitization, public interest programmers, community mobilization, educating children on their rights, etc. can additionally play an important role to change attitudes. Over-crowded classes, insufficient resources, and first-generation learners can create an environment full of stress. However, the report indicates that the children are not responsible for the problems that teachers face. They should not be penalized for the lack of resources.

Gullipalli, in INDIA: A chance to rethink school discipline states that India is certainly not alone in facing the challenge of corporal punishment. A recent Human Rights Watch report documents the widespread use of corporal punishment in U.S. public schools also. Positive Behavioral Support systems in some U.S., Canadian, and Australian schools require researchers and students to work together to develop shared norms and expectations for behavior. Children are involved in deciding what acceptable behavior is and are treated as partners in matters of school discipline. Rather than following up attention-drawing with censure and punishment, this method uses discipline as an opportunity to build children's skills to behave differently the next time a similar situation arises. However, a report by UNICEF states, "Teachers, like parents, tend to view children as passive recipients of adult wisdom and their own ability to exert control, diminish the respect they receive from children and produce bad behavior. Yet, as with families, the evidence points to the contrary".

The article continues to state that research from the UK, demonstrates that when children feel respected and are involved in decisions affecting school life, the relationships between staff and students improve. Also educational outcomes, improve leading to less conflict and violence and greater commitment to education. Schools in general and discipline policies in particular often offer little space for student input and participation. Schools are the environments best suited for building children's participation and competence. Schools must recognize both children's capacities, as they develop over time, and their own role in developing them. School discipline policies that start with the recognition of children's unique capacity to participate in securing their own well-being and development will lay the foundation for schools that are safer, better run, and better able to contribute to the education and development of their students 


\section{China}

UNICEF: Convention on the Rights of the Child indicates that the mission is to advocate for the protection of children's rights, to help meet their basic needs, and to expand their opportunities to reach their full potential. UNICEF is guided in doing this by the provisions and principles of the Convention on the Rights of the Child. Built on varied legal systems and cultural traditions, the Convention is a universally agreed set of non- negotiable standards and obligations. These basic standards - also called human rights - set minimum entitlements and freedoms that should be respected by governments. They are founded on respect for the dignity and worth of each individual, regardless of race, color, gender, language, religion, opinions, origins, wealth, birth status or ability and therefore apply to every human being everywhere. With these rights comes the obligation on both administration and individuals not to infringe on the equal rights of others. These standards are both interdependent and indivisible; we cannot ensure some rights without- or at the expense of —other rights.

China is a ratified signatory to the UN Rights of the Child article 28(2) which binds nations to "...take all appropriate measures to ensure that school discipline is administered in a manner consistent with the child's human dignity and in conformity with the present Convention." Further, China's own Compulsory Education Law (last revised in 2006), orders that teachers "....must not impose any corporal punishment on students or other acts of insult to human dignity, and must not violate legitimate rights and interests of students."

Despite being banned by Chinese law, incidents of corporal punishment continue to be reported. Gunatillake, 2009 "Classroom Discipline: Challenges for Chinese Policymakers" in China Daily, reported that 60\% of Chinese children had been subjected to some form of excessive classroom discipline. This country faces various challenges to reduce the occurrence of these incidences and even eliminate them. The report asserted that in many cases, particularly in less developed areas of China, parents did not equate disciplinary measures towards their children with abuse. As in India, teachers are generally feared and revered, and they enjoy a level of authority that is rarely challenged. Similarly, teachers in China are under immense pressure, with large classes, a need to ensure good grade averages for the reputation of the school, and an education system that demands a certain style of teaching. This traditional style of teaching fails to engage students in a meaningful way, creating an ethos of distraction and misbehavior resulting in disciplinary action.

Gunatillake, in February 2009 stated that a primary school boy named Taotao (not his real name) was attending basketball practice on a playing field being shared with a middle school running class. Mistaking Taotao for one of his students, the middle school sports teacher enquired as to why the boy was not running as instructed. When Taotao replied that he was not a middle school student and did not know the teacher, he was pulled by the collar and kicked to the ground. After getting back up, the teacher slapped the boy's face and again kicked him to the ground. Taotao suffered facial injuries, minor concussion, hearing impairment and bruising, among others. The boy's family received 8,000 RMB from the teacher to cover hospital expenses, and Taotao's parents chose not to take the matter further. As a result, no further action was reported to have been taken to discipline the teacher involved.

The Convention on the Rights of the Child is the first legally binding international instrument to incorporate the full range of human rights - civil, cultural, economic, political and social. By agreeing to undertake the obligations of the Convention (by ratifying or acceding to them), UNICEF: Convention on the Rights of the Child indicates that national governments have committed themselves to protecting and ensuring children's rights, and they have agreed to hold themselves accountable for this commitment before the international community. States are obliged to develop and undertake all actions and policies in the light of the best interests of the child.

The report continues to state that China's education system is in the process of undergoing significant systemic reform but this will take a while to become effective. This would require an evolution between teachers and students across the country. Premier Wen Jiabao suggested that, "Teachers should teach students to think, live and get along with others, in addition to knowledge," highlighting China's (and much of the rest of Asia's) typically regimented teaching methods.

\section{USA}


States with Corporal Punishment in School by Dennis Randall states that parents and educators are sharply divided about spanking a child for breaking school rules. Twenty-one states allow some form of corporal punishment while twenty-nine have banned the practice. Some questions that arose were the following: How is corporal punishment working? Should the practice continue? If you live in a state where such punishment is banned, would you support its re-introduction into the classroom if you moved to a state where it is allowed? This question is currently under serious consideration in the United Kingdom. The table below is rather revealing of the United States.

Where the states stand on corporal punishment:

\begin{tabular}{|c|c|c|c|c|c|}
\hline Alabama & Legal & Kentucky & Legal & North Dakota & Illegal \\
\hline Alaska & Illegal & Louisiana & Legal & Ohio & Legal \\
\hline Arizona & Legal & Maine & Illegal & Oklahoma & Legal \\
\hline Arkansas & Legal & Maryland & Illegal & Oregon & Illegal \\
\hline California & Illegal & Massachusetts & Illegal & Pennsylvania & Illegal \\
\hline Colorado & Legal & Michigan & Illegal & Rhode Island & Illegal \\
\hline Connecticut & Illegal & Minnesota & Illegal & South Carolina & Legal \\
\hline Delaware & Illegal & Mississippi & Legal & South Dakota & Illegal \\
\hline District of Columbia & Illegal & Missouri & Legal & Tennessee & Legal \\
\hline Florida & Legal & Montana & Illegal & Texas & Legal \\
\hline Georgia & Legal & Nebraska & Illegal & Utah & Illegal \\
\hline Hawaii & Illegal & Nevada & Illegal & Vermont & Illegal \\
\hline Idaho & Legal & New Hampshire & Illegal & Virginia & Illegal \\
\hline Illinois & Illegal & New Jersey & Illegal & Washington & Illegal \\
\hline Indiana & Legal & New Mexico & Legal & West Virginia & Illegal \\
\hline Iowa & Illegal & New York & Illegal & Wisconsin & Illegal \\
\hline Kansas & Legal & North Carolina & Legal & Wyoming & Legal \\
\hline
\end{tabular}

In the 2005-2006 school year, 223,190 school children in the U.S. were subjected to physical punishment. This is a significant drop of almost $18 \%$, continuing a steady trend from the early $1980 \mathrm{~s}$.

\begin{tabular}{|l|c|c|}
\hline \multicolumn{1}{|c|}{ State } & Number of Students Hit & Percentage of Total Students \\
\hline Alabama & 33,716 & 4.5 \\
\hline Arkansas & 22,314 & 4.7 \\
\hline Arizona & 16 & $<0.0$ \\
\hline Colorado & 8 & $<0.0$ \\
\hline Florida & 7,185 & .3 \\
\hline Georgia & 18,249 & 1.1 \\
\hline Idaho & 111 & .04 \\
\hline Indiana & 577 & .05 \\
\hline Kansas & 50 & .01 \\
\hline Kentucky & 2,209 & .3 \\
\hline Louisiana & 11,080 & 1.7 \\
\hline Missouri & 5,159 & .6 \\
\hline Mississippi & 38,131 & 7.5 \\
\hline North Carolina & 2,705 & .2 \\
\hline New Mexico & 705 & .2 \\
\hline Ohio & 672 & .04 \\
\hline Oklahoma & 14,828 & 2.3 \\
\hline South Carolina & 1,409 & .2 \\
\hline Tennessee & 14,868 & 1.5 \\
\hline Texas & 49,197 & 1.1 \\
\hline Wyoming & 0 & 0 \\
\hline
\end{tabular}


The 10 worst states, by percentage of students struck by educators in the 2005-2006 school year: Data released March, 2008.

\begin{tabular}{|c|c|c|}
\hline Rank & State & Percentage \\
\hline 1 & Mississippi & 7.5 \\
\hline 2 & Arkansas & 4.7 \\
\hline 3 & Alabama & 4.5 \\
\hline 4 & Oklahoma & 2.3 \\
\hline 5 & Louisiana & 1.7 \\
\hline 6 & Tennessee & 1.5 \\
\hline 7 & Texas & 1.1 \\
\hline 8 & Georgia & .6 \\
\hline 9 & Missouri & .3 \\
\hline
\end{tabular}

The report states that African-American students comprised 17\% of all public school students in the U.S., and $36 \%$ of those had corporal punishment inflicted on them, more than twice the rate of white students. Almost $40 \%$ of all the cases of corporal punishment occur in just two states: Texas and Mississippi, and if Arkansas, Alabama and Georgia, are added then these five states account for almost three quarters of all the nation's school paddling.

\section{Number of Students Struck Each Year in U.S. Public Schools}

\begin{tabular}{|l|c|c|c|}
\hline & \#White \% & \# Black \% & Tot. Kids hit \\
\hline 1976 & 992,67565 & 447,31429 & $1,521,8963.5$ \\
\hline 1978 & 940,46765 & 411,27129 & $1,438,3173.4$ \\
\hline 1980 & 901,03264 & 403,38629 & $1,408,3033.4$ \\
\hline 1982 & no statistical projection was made this year & \\
\hline 1984 & 852,42764 & 374,31528 & $1,332,3173.3$ \\
\hline 1986 & 659,22460 & 345,41131 & $1,099,7312.7$ \\
\hline 1988 & 549,57261 & 255,29628 & $898,3702.2$ \\
\hline 1990 & 346,48856 & 208,54334 & $613,7601.5$ \\
\hline 1992 & 295,05053 & 215,68439 & $555,5311.3$ \\
\hline 1994 & 256,36354 & 182,39439 & $470,6831.1$ \\
\hline 1997 & 241,40653 & 178,11439 & $457,7541.0$ \\
\hline 1998 & 199,57255 & 135,52337 & $365,0580.8$ \\
\hline 2000 & 181,68953 & 132,06539 & $342,0380.7$ \\
\hline 2003 & 159,44653 & 115,81938 & $301,0160.6$ \\
\hline 2004 & 143,00253 & 104,62738 & $272,0280.57$ \\
\hline 2006 & 119,33953 & 79,61336 & $223,1900.46$ \\
\hline
\end{tabular}


Further details on the above three tables' data and the study can be found at the U.S. Department of Education, Office for Civil Rights.

From the data, I can deduce that the classroom management skills need further work in the teaching and learning of pre-service teachers. External support also needs to be provided for the schools, especially the teachers. The numbers show a decline in corporal punishment but in my opinion any child encountering corporal punishment is one too many. Classroom management professional development courses should be made mandatory for every teacher to attend on a yearly basis. A school environment should be a safe place for all children. Parents and guardians too are part of the bigger picture of a child's behavior in the school. It is not an issue within the school itself but around every aspect of the child's day. I remember one of my daughters in her elementary school was asked to rake leaves as part of a disciplinary measure and she was relieved when she saw me come to pick her up thinking her assignment was complete. Instead, I supported the teacher in charge of the afterschool program and had my daughter finish the job. My support of the teacher was sufficient for my daughter to accept her behavior as equally important to me. I think I prefer any day the beautifying of the school grounds with children's help far more than corporal punishment. This behavior, incidentally, was never repeated by my daughter. Wolhuter and Oosthuizen (2003: 454) in U.S.: Corporal Punishment and Paddling Statistics by State and Race mentions that from a learner's perspective, lack of parent involvement is the biggest cause of disciplinary problems.

In my quest for alternative classroom management strategies I came across an interesting study conducted in South Africa.

\section{Africa}

An article by Marais and Meier, on Disruptive behaviour in the Foundation Phase of schooling states that "Teachers in South Africa are becoming increasingly distressed about disciplinary problems in schools, as corporal punishment has been outlawed by legislation, such as the Constitution of the Republic of South Africa (Republic of South Africa, 1996a) and the South African Schools Act (Republic of South Africa 1996b). Some sectors of society have reacted positively claiming that the said legislation affirms human dignity but others have expressed concern, contending that there are no viable alternatives to corporal punishment."

Teachers who relied on corporal punishment to reduce disruptive behavior had to develop alternative methods. Levin and Nolan, 2006, identified classified disruptive behavior into four basic categories: a behavior that interferes with the teaching and learning by distracting other learners during class, by refusing to follow directions, or displaying aggressive behavior; a behavior that interferes with other learners to learn by continually calling out while the teacher is explaining content; a behavior that is psychologically or physically unsafe where a student leans on the back legs of a chair, portrays unsafe use of tools or laboratory equipment that threatens others, and constantly teases and harasses other students; and finally a behavior that causes the destruction of property through vandalism in the classroom.

Some of the observations by teachers in South Africa seemed familiar to me in both my experiences as a teacher in the United Kingdom and the United States. According to the teachers, students talked while learning content or completing a task. Even after warnings, students continued to talk, laugh and make noise. Playing with stationery, throwing objects around, and disobeying the teacher were all too common. There are many aspects to understanding why disruptive behavior in a classroom can cause discipline problems. There is no one single issue, but a collective of several factors that bring about unruly or unacceptable behavior among students. Lack of respect for authority and rules, overcrowded classrooms, as well as Attention Deficit Disorder (ADD) and/or Attention Deficit and Hyperactivity Disorder (ADHD) were some mentioned in the article. In the US and the UK, I also experienced a language barrier among some students that added to discipline issues. It became apparent through this research that disruptive behavior in the Foundation Phase posed a major challenge for educators. An important discovery made during the research and which related to all types of disruptive behavior was a lack of parental care and adult role models in society. It is primarily in the family where students learn to act morally and thus I feel that parents and guardians of the students need to be held equally accountable. 
Furthermore, I think the measures need to extend into the school system where the discipline must be consistent with the school policy. This does not mean using corporal punishment but rather developing stronger professional development on a regular basis and a good command of administrative support where all students are held accountable for their actions along with their adult caregivers.

\section{United Kingdom}

Corporal punishment in British state schools and private schools receiving public funding was banned by parliament in 1987. In May 1985, The Guardian Newspaper reported the findings of the Advisory Center for Education (ACE). An average 4.7 recorded beatings per 100 pupils in secondary schools each year, whereas in the elementary schools an annual rate was at least one beating per 100 pupils. ACE concluded: "Extrapolating nationally produces an estimate that there are nearly 250,000 officially recorded beatings in each school year in England and Wales - or one every 19 seconds."

The above mentioned data are astoundingly high and appalling especially if The Guardian Newspaper, London, January 2000 states that a survey suggested that half of parents would like to see the return of corporal punishment in schools in the UK - which was outlawed 14 years ago. This is indicative of the return of higher punitive measures.

The BBC News reported the following data in January 2000. Sixty-six percent of parents believe behavior has declined in the last 10 years. Fifty-one percent would like to see corporal punishment reintroduced; forty-seven percent are opposed. Sixty-seven percent think teachers should be paid by performance. Forty-two percent say standards have improved in the last 10 years; twenty-six percent say they have fallen.

A small minority of unruly pupils can make life difficult for teachers and do real damage to the learning and attainment of other pupils in a class. Sir Alan Steer stated in the BBC News reported in 2005 that the changes recommended strengthen the authority of schools, giving them the confidence to take action and send a clear message to parents and pupils that they also have a responsibility in dealing with the problem. It also indicated that teachers needed "clear and unambiguous" rights to discipline pupils and to use "reasonable force" to restrain difficult pupils. The right to restrain pupils was, however, in the Education Act of 1996. What is reasonable? How can one define reasonable force from one individual to another? I believe this to be ambiguous and can be carried too far into corporal punishment.

Education Secretary Ruth Kelly said: "The Government has made tackling poor behaviour a major priority, providing increased powers and resources." Ofsted also tells us that behavior is good in most schools most of the time. But some schools still face real discipline challenges because there is too little consistency in dealing with poor behavior. There is still too much low-level disruption to lessons - backchat, rudeness, calling out in class - that makes teaching and learning more difficult. Proposals below help bring change not just to the rules but to the culture reaffirming respect in classrooms and putting teachers firmly in charge."

Some key proposals mentioned in BBC News: "Teachers get discipline rights" were stronger, clearer legal rights for schools; greater use of parenting contracts and orders; compulsory parental supervision of excluded pupils; a national charter of rights and responsibilities for teachers, pupils and parents; pupils' behavior must be evaluated by schools for Ofsted.

Through this research it appears that corporal punishment seems to be favored, but what implications will this bear on the pupil's emotional status? Disciplining the child is not the ultimate responsibility of the teacher alone. It is shared with the family, school and community. All need to come together and take full responsibility and stop blaming the other. Corporal punishment may be a temporary measure that causes anguish and pain in the pupil, but what about self esteem, and the emotional and perhaps physical scars that develop in students? All pre-service teachers should be mandated to take a classroom management course during their student teaching. The Virginia Department of Education requires this of all pre-service teachers. I ask all educators to stand united against corporal punishment and agree to alternative methods of discipline. This would be another research in the future as to what successful methods are there and what alternative methods of discipline can be implemented. 


\section{AUTHOR INFORMATION}

Usha Rajdev is an Associate Professor in education at Marymount University in Arlington, Virginia. Her research foci include Ethics: in the classroom management and children's errors and misconceptions in mathematics. She teaches math and science methodology to both undergraduate and graduate students through a constructivist approach. She is also a Counselor for Kappa Delta Pi, a faculty advisor for National Science Teachers Association Student Chapter, and an NCATE assessment coordinator in Marymount University's education department. She has conducted two study abroad service learning projects in India. E-mail: usha.rajdev@ marymount.edu

\section{REFERENCES}

1. $\quad$ BBC News: "Parents "back corporal punishment" "http://news.bbc.co.uk/2/hi/uk news/education/593949.stm retrieved on 2/19/2011.

2. BBC News: "Teachers get discipline rights" http://news.bbc.co.uk/2/hi/uk_news/education/4361770.stm retrieved 2/19/2011

3. Boylan, M. (2011), ed "Duties to Children" The Morality and Global Justice Reader, (Boulder, CO: Westview): 385-404.

4. Campaigning for law reform to prohibit corporal punishment: Understanding the need for prohibition Summary Briefing 1 (June 2009) http://www.endcorporalpunishment.org/pages/pdfs/briefings/Law\%20Reform\%20Briefing\%201\%20\%20Understanding\%20the\%20need\%20for\%20prohibition.pdf retrieved 2/20/2011

5. Gullipalli, V "INDIA: A chance to rethink school disciple" http://www.crin.org/violence/search/closeup.asp?infoID=21032 retrieved 6/15/2010

6. Gunatillake, S. 2009 "Classroom Discipline: Challenges for Chinese Policymakers" http://www.chinaeducationblog.com/chinese-students/2009-07-24/classroom-discipline-challenges-forchinese-policymakers/ retrieved 2/10/2011

7. Marais, P. and Meier, C. Disruptive behaviour in the Foundation Phase of schooling. S. Afr j. educ.[online].2010, vol.30, n.1 [cited 2011-04-03], pp. 41-57. http://www.scielo.org.za/scielo.php?script=sci_arttext\&pid=S025601002010000100004\&lng=en\&nrm=iso

8. $\quad$ ISSN 0256-0100.

9. Randall, D. 'States with Corporal Punishment in School' http://school.familyeducation.com/classroomdiscipline/resource/38377.html retrieved 3/29/11

10. Roa, S "Positive Discipline in the Classroom: Spare the Rod and Save the Child" http://www.lovingyourchild.com/2010/10/positive-discipline-classroom-spare-rod-save-child/ retrieved $6 / 15 / 2010$

11. The Guardian Newspaper, "Sparing the rod" http://www.corpun.com/uks00701.htm\#18715 retrieved on 2/19/2011)

12. UN Committee on the Rights of the Child (CRC), CRC General Comment No. 8 (2006): The Right of the Child to Protection from Corporal Punishment and Other Cruel or Degrading Forms of Punishment (Arts. 19; 28, Para. 2; and 37, inter alia), 2 March 2007, CRC/C/GC/8, available at: http://www.unhcr.org/refworld/docid/460bc7772.html [accessed 4 April 2011]

13. UNICEF: Convention on the Rights of the Child http://www.unicef.org/crc/ as of May 18, 2009.

14. UNICEF: 'All You Want to Know About Corporal Punishment' http://www.unicef.org/india/child_protection 5449. htm

15. Wolhuter and Oosthuizen (2003) in U.S.: Corporal Punishment and Paddling Statistics by State and Race. U.S. Department of Education, Office for Civil Rights http://ocrdata.ed.gov/ 